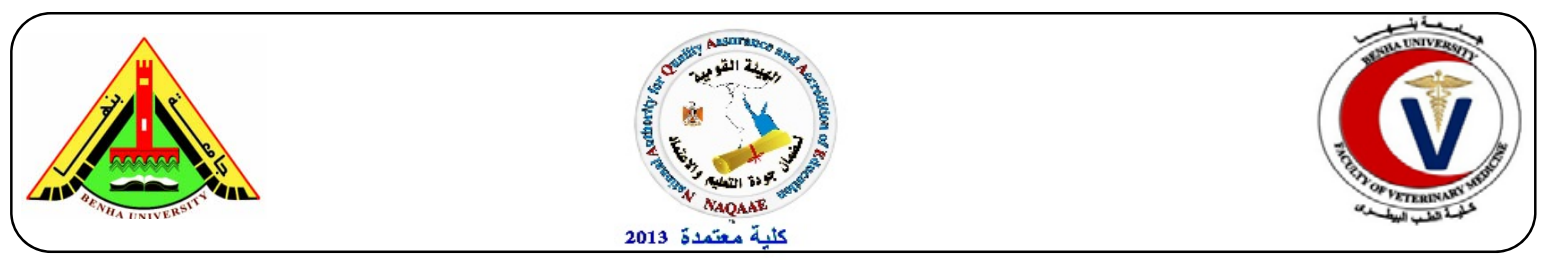

\title{
Molecular Screening Of Virulence Genes In Avian Pathogenic Esherichia Coli
}

\author{
Ashraf A. Abd El Tawab ${ }^{1}$, Ahmed M. Ammar ${ }^{2}$, Fatma I. El-Hofy ${ }^{1}$, Mokhtar Abdel Hakeem ${ }^{3}$ and \\ Noha M. Abdel Galil ${ }^{3}$ \\ ${ }^{1}$ Bacteriology, Immunology and Mycology Dept. Fac. Vet. Med., Benha Univ., ${ }^{2}$ Bacteriology, \\ Immunology and Mycology Dept., Fac. Vet. Med. Zagazig Univ. ${ }^{3}$ Animal Health Research Institute \\ (Zagazig branch).
}

\begin{abstract}
A B S T R A C T
Avian pathogenic Escherichia coli (APEC) causes colibacillosis, which is one of the main causes of economic losses in the poultry industry worldwide. This disease occurs only when the E. coli infecting strain presents virulence factors (encoded by specific genes) that enable the adhesion and proliferation in the host organism. Herin, 15 E. coli strains of different serogroups isolated from birds with colibacillosis were assigned to their phylogenetic groups and analyzed for the occurrence of 11 virulence associated genes. phylogenetic typing showed that group B2 was the largest $(33.3 \%, 5 / 15)$ followed by group B1 $(26.7 \%, 4 / 15)$, groups A and D were similar in size $(22.1 \%, 19 / 86)$. The virulence profiles showed that ompA was found in most isolates $14 / 15(93.3 \%)$. The iss gene was found in 13/15 $(86.6 \%)$. Followed by traT and iutA genes which were found in $12 / 15(80 \%) . c v a C$, stx2 and tsh genes were present in $9 / 15(60 \%), 7 / 15(46 \%)$ and of the isolates, respectively. Only one isolate gave positive amplification for stx 1 and ibeA genes each. The hly gene was not encountered in any of the tested isolates.
\end{abstract}

keywords: Avian pathogenic Escherichia coli (APEC), phylogenetic analysis, virulence genes.

\section{INTRODUCTION}

$\mathrm{C}$ olibacillosis is one of the most important bacterial disease of poultry, the economic impact of this disease is difficult to assess, and it is widely assumed substantial based on losses due to mortalities, condemnations and lost productivity (Barnes et al., 2008). Avian pathogenic Escherichia coli (APEC), the etiologic agent of this disease, belonged to the broad E. coli pathotype known as extraintestinal pathogenic E. coli (ExPEC) (Russo and Johnson, 2000; Johnson et al., 2002; Smith et al., 2007). ExPEC are characterized by their ability to cause disease outside the intestinal tract (Russo and Johnson, 2000; Johnson et al., 2002; Kaper, 2005). Colonization of the trachea and air sacs considered the first step of a systemic infection by APEC, followed by the colonization of the liver and the pericardium, with subsequent bacteremia (Dziva and Stevens, 2008). To adhere, colonize, invade, and cause infection, APEC strains possess diverse set of virulence factors that enable their extraintestinal lifestyle and make them distinct from commensal and diarrheagenic E. coli strains (Russo and Johnson, 2000). These virulence factors, which involved in colonization, adhesion, invasion and survival the host defenses are adhesins, invasins, toxins, iron acquisition system (siderophores) and protictins (Ewers et al., 2004; Ewers et al., 2007; Rodriguez-Siek, et al., 2005 and Johnson et al., 2008).These virulence genes rarely found in the same isolate and that they can present either individually or polygenically with varying 
frequencies (Delicato et al., 2003 and Vandekerchove et al., 2005). Phylogenetic analysis of E.coli shows that there are four main phylogenetic groups of E.coli, designated A, B1, B2 and D (Clermont et al., 2000).Worldwide phylogenetic analyses have demonstrated that virulent extraintestinal $E$. coli strains belong mainly to group B2 and, to a lesser extent, to group D. In contrast, most of the commensal strains are associated with group A or group B1(Takahashi et al., 2006; Moreno et al., 2008 and Basu et al., 2013). Recent studies have shown that some APEC clones are very similar to extraintestinal pathotypes that affect humans (UPEC: uropathogenic Escherichia coli and NMEC: neonatal meningitis-causing Escherichia coli). These APEC strains are indistinguishable from human ExPEC by the possession of certain virulence factors and phylogenetic groups (Rodriguez-Siek et al., 2005; Ewers et al.,2007; Johnson et al., 2008; Zhao et al., 2009; Tivendale et al., 2010; Vincent et al., 2010; Bergeron et al., 2012 and Jakobsen et al., 2012). For this reason, some authors pointed to poultry as a reservoir for human ExPEC, and the possibilities exist for the transfer of APEC to human, which suggests a public health hazard (Vincent et al., 2010; Bergeron et al., 2012 and Jakobsen et al., 2012). In view of these considerations, this study was aimed to characterize E.coli isolates referring to their phylogenetic groups, presence of some virulence associated genes which are frequently found in APEC including eaeA, stx1, stx2, hly, iss, tsh, ompA, tra $\mathrm{T}$, ibe A, cvaC and iutA as well as DNA sequencing for 2 of the isolated genes ( $\mathrm{cvaC}$ and iss).

\section{MATERIAL AND METHODS}

\subsection{Sampling, bacteriological examination and serotyping:}

This study investigated 451 samples from freshly slaughtered broilers showed different disease manifestations clinically diagnosed as colibacllosis obtained from farms of different localities in Sharkia and
Dakahlia. Samples were cultured on MacConkey agar and (EMB) agar (Calnek et al., 1997). Then they were further identified using conventional biochemical tests in addition to confirmation by RapID ONE system (Remel), 25 isolates that were preliminary identified biochemically as $E$. coli were subjected to serological identification using slide agglutination test according to (Edward and Ewing, 1972).

\subsection{Phylogenetic analysis of E. coli isolates:}

E. coli phylogenetic grouping was accomplished by PCR as previously described by(Clermont et al., 2000). DNA of 15 isolates were extracted by QIAamp DNA mini kit instructions according to manufacture instructions, then placed in a PTC-100 programmable thermalcycler in a final volume of $25 \mu \mathrm{l}$ consisting of $12.5 \mu \mathrm{l}$ of DreamTaq TM Green Master Mix (2X) (Fermentas, USA), $1 \mu 1$ of each primer (Sigma, USA), $7 \mu$ l of template DNA and nuclease-free water up to $25 \mu \mathrm{l}$. Amplified PCR products was electrophoresed on $1.5 \%$ agrose gel in tris acetate EDTA and visualized by UV transilluminator. This method designates strains to one of four phylogenetic groups (A, B1, B2, and D) based on the presence of two genes (chuA and $y j a A$ ) and a specific DNA fragment(TSPE4.C2). Both chuA and TspE4.C2 negative and positive E. coli strains were grouped into group A and B2, respectively, and the chuA-negative and TspE4.C2-positive, and the chuA positive and yjaA-negative $E$. coli strains were grouped into $\mathrm{B} 1$ and $\mathrm{D}$, respectively. The used primers in this analysis are listed in Table (1).

\subsection{Detection of Virulence Genes:}

DNA of $15 \mathrm{E}$. coli isolates were extracted as previously mentioned in addition to plasmid extraction according to QIAprepSpin Miniprep Kits catalogue No. 27104. PCR was used to amplify some virulence genes of interest in APEC. Multiplex PCR was used for the detection of seven virulence genes (eae, traT, ibeA, 
iutA, cvaC, Stx1and Stx2) in 3 different cycling protocols and 4 uniplex PCR systems were used for detection of other four virulence genes (tsh, hly, ompA and iss) in the same isolates. The primer sets, sequences, amplification product size and the positive control strain for each gene used in PCR programs were listed in Table (2).

\subsection{DNA sequencing:}

iss and cvaC genes were sequenced each in 2 E. coli isolates representing serogroups O78 and $\mathrm{O} 157$ using Big dye Terminator V3.1 cycle sequencing kit.(Perkin-Elmer, Foster city, CA) then the samples were read using Applied Biosystems 3130 automated DNA Sequencer (ABI, 3130, USA). The sequence analysis were performed with BIO EDIT and the basic local alignment search tool software (BLAST) by comparing genes under study with corresponding genes on the gene bank then deposited on the gene bank.

\section{RESULTS}

The obtained results revealed that, $236 \mathrm{E}$. coli isolates were successfully recovered with a total percent $52.3 \%$ (representing 64 , 51, 48 and 52 out of 100 examined lung, liver, heart blood and trachea respectively, and 21 out of 51examined spleen). Serogrouping of $25 \mathrm{E}$. coli isolates revealed that $\mathrm{O} 78$ was the most predominant serogroup with a percentage of ( $20 \%)$ followed by $\mathrm{O} 157$ and $\mathrm{O} 27$ (16\%) each, other serotypes as O168, O125 were also recorded with percentage of (12\%) and O115 with percentage of $(8 \%)$ while 4 isolates were untypable.

\subsection{Phylogenetic typing:}

Fifteen APEC strains were assigned to four different phylogenetic groups. the majority of examined strains fell into Group B2 5/15 $(33.3 \%$,) followed by group B1 $(26.7 \%)$, groups A and D were detected with the same percentage 19 out of $86(22.1 \%)$. the results were presented in Fig. (1) and Table (3).

\subsection{Virulence genotyping:}

The fifteen E. coli isolates were examined for the presence of 11 virulence associated genes. The virulence profiles showed that ompA was found in most isolates 14 out of 15 with percent $93.3 \%$ and gave an amplification product sizes of 919 bp (Fig.5). The iss and iutA genes gave positive amplification at 266 and $300 \mathrm{bp}$ respectively. iss was found in 13 isolates $(86.6 \%)$ and iutA 12 isolates $(80 \%)$ as shown in (Fig. 7 and 3), traT gene was detected in 12 out of 15 examined isolates $(80 \%)$ with amplification product size of 307 bp (Fig. 2 ), in addition to $c v a \mathrm{C}$, st 22 and tsh genes were present in $9 / 15(60 \%)$, $7 / 15(46 \%)$ and $5 / 15(33.3 \%)$ of the examined isolates, respectively with an amplicon product sizes of $760 \mathrm{bp}, 779 \mathrm{bp}$ and $620 \mathrm{bp}$, respectively as presented in (Fig. 3, 4 and 6). Only one isolate harbored $e a e \mathrm{~A}$, ibe A and $s t x 1$ genes each. They gave positive amplification at $248 \mathrm{bp}, 342 \mathrm{bp}$ and 614 bp, respectively (Fig. 2 and 4). Whereas, the hly gene hasn't been found in any of the isolates. Distribution of virulence genes in fifteen E. coli isolates and the relationship between APEC isolates phylogenetic group and gene prevalence shown in Table (3) and thier relation with isolates serogroups represented in Table (4)

\subsection{DNA sequencing:}

iss and $c v a C / c v i$ genes of 4 APEC isolates representing serogroups $\mathrm{O} 157$ and $\mathrm{O} 78$ were subjected to DNA sequencing followed by analysis of the genes through their alignment with previously deposited genes on the gene bank showing high nucleic acid homogeneity between the two genes under study and the same genes on the gene bank harbored by different $E$. coli isolates published on the gene bank. The nucleotide sequences of iss genes of $E$. coli under study were deposited into gene bank under the following accession numbers KU904253, KU904254 while the nucleotide sequences of $c v a C / c v i$ genes of 
Table (1): The oligonucleotide primers used for phylogenetic grouping of $E$. coli isolates:

\begin{tabular}{llcl}
\hline Gene & Primer sequence (5'-3') & Amplified product & Reference \\
& & & \\
\hline ChuA & GAC GAA CCA ACG GTC AGG AT & $279 \mathrm{bp}$ & \\
& TGC CGC CAG TAC CAA AGA CA & & \\
\multirow{2}{*}{ YjaA } & TGA AGT GTC AGG AGA YGC TG & $211 \mathrm{bp}$ & Jeong et al., (2012) \\
& ATG RAG AAT GCG TTC CTC AAC & & \\
\multirow{2}{*}{ tspE4C2 } & GAG TAA TGT CGG GGC ATT CA & $152 \mathrm{bp}$ & \\
& CGC GYC AAC AAA GTA TTR CG & & \\
\hline
\end{tabular}

Table

(2):

Oligonucleotide primers used for genotypic identification of $E$. coli isolates:

\begin{tabular}{|c|c|c|c|c|}
\hline Gene & Primer Sequence (5'-3') & $\begin{array}{l}\text { Amplified } \\
\text { product }\end{array}$ & Reference & $\begin{array}{l}\text { Positive } \\
\text { control } \\
\text { Reference } \\
\text { strain }\end{array}$ \\
\hline EaeA & $\begin{array}{l}\text { ATGCTTAGTGCTGGTTTAGG } \\
\text { GCCTTCATCATTTCGCTTTC }\end{array}$ & $248 \mathrm{bp}$ & $\begin{array}{l}\text { Bisi-Johnson et al., } \\
2011\end{array}$ & M58154 \\
\hline $\operatorname{traT}$ & $\begin{array}{l}\text { GATGGCTGAACCGTGGTTATG } \\
\text { GATGGCTGAACCGTGGTTATG }\end{array}$ & $307 \mathrm{bp}$ & Kaipainenet al., 2002 & NC-005327.1 \\
\hline$i b e A$ & $\begin{array}{l}\text { TGGAACCCGCTCGTAATATAC } \\
\text { CTGCCTGTTCAAGCATTGCA }\end{array}$ & 342 bp & Ewers et al., 2007 & AY248744.1 \\
\hline iutA & $\begin{array}{l}\text { GGCTGGACATGGGAACTGG } \\
\text { CGTCGGGAACGGGTAGAATCG }\end{array}$ & $300 \mathrm{bp}$ & Yaguchietal., 2007 & JX446685.1 \\
\hline cvaC & $\begin{array}{l}\text { CACACACAAACGGGAGCTGTT } \\
\text { CTTCCCGCAGCATAGTTCCAT }\end{array}$ & $760 \mathrm{bp}$ & Dipineto et al., 2006 & СР01031601 \\
\hline stx 1 & $\begin{array}{l}\text { ACACTGGATGATCTCAGTGG } \\
\text { CCATGACAACGGACAGCAGTT }\end{array}$ & 614 bp & Dipineto et al., 2006 & AJ413986 \\
\hline stx2 & $\begin{array}{l}\text { CCTGTCAACTGAGCAGCACTTTG } \\
\text { AGCTATCGCGATTGCAGTG }\end{array}$ & 779 bp & Dipineto et al., 2006 & FN252457 \\
\hline ompA & $\begin{array}{l}\text { GGTGTTGCCAGTAACCGG } \\
\text { GGTGGTGCACTGGAG TGG }\end{array}$ & 919 bp & Ewers et al., 2007 & AF23428.1 \\
\hline tsh & $\begin{array}{l}\text { AGT CCA GCG TGA TAG TGG } \\
\text { AACAAGGATAAGCACTGTTCTGGCT }\end{array}$ & $620 \mathrm{bp}$ & Delicato et al., 2003 & JX46685.1 \\
\hline hly & $\begin{array}{l}\text { ACCATATAAGCGGTCATTCCCGTCA } \\
\text { ATGTTATTTTCTGCCGCTCTG }\end{array}$ & $\begin{array}{l}1177 \mathrm{bp} \\
260 \mathrm{bp}\end{array}$ & Piva et al., 2003 & NG036728.1 \\
\hline iss & $\begin{array}{l}\text { CTATTGTGAGCAATATACCC } \\
\text { CTATTGTGAGCAATATACCC }\end{array}$ & & Yaguchi et al., 2007 & DQ309287.1 \\
\hline
\end{tabular}


Table (3): Relationship between APEC isolates phylogenetic group and gene prevalence

\begin{tabular}{|c|c|c|c|c|c|c|c|c|c|c|c|c|c|}
\hline $\begin{array}{c}\text { Isolate } \\
\text { No. }\end{array}$ & EaeA & traT & ibeA & iutA & $c v a C$ & stx1 & st $x 2$ & tsh & hly & ompA & iss & No.ofvirul.genes & $\begin{array}{l}\text { Phylo. } \\
\text { Group }\end{array}$ \\
\hline 1 & - & - & - & + & - & - & - & - & - & - & + & 3 & A \\
\hline 2 & - & + & + & + & + & - & + & + & - & + & - & 7 & B1 \\
\hline 3 & - & - & - & - & + & - & - & - & - & + & + & 3 & A \\
\hline 4 & - & - & - & - & - & - & - & - & - & + & + & 2 & A \\
\hline 5 & + & + & - & + & - & - & - & + & - & + & + & 6 & B1 \\
\hline 6 & - & + & - & + & + & - & - & - & - & + & + & 5 & $\mathrm{D}$ \\
\hline 7 & - & + & - & + & + & - & - & + & - & + & + & 6 & B2 \\
\hline 8 & - & + & - & - & + & + & - & - & - & + & + & 5 & B1 \\
\hline 9 & - & + & - & + & + & - & + & - & - & + & + & 6 & B1 \\
\hline 10 & - & + & - & + & + & - & + & - & - & + & + & 6 & $\mathrm{D}$ \\
\hline 11 & - & + & - & + & - & - & + & + & - & + & - & 5 & $\mathrm{~B} 2$ \\
\hline 12 & - & + & - & + & - & - & + & - & - & + & + & 5 & B2 \\
\hline 13 & - & + & - & + & - & - & + & - & - & + & + & 5 & B2 \\
\hline 14 & - & + & - & + & + & - & + & + & - & + & + & 7 & B2 \\
\hline 15 & - & + & - & + & + & & - & - & - & + & + & 5 & $\mathrm{D}$ \\
\hline
\end{tabular}

Table (4):Relationship between E. coli serogroups, phylogenetic group and virulence genes pattern

\begin{tabular}{|c|c|c|c|}
\hline Strain no. & Virulence genes & Serogroup & Phylo.group \\
\hline $1(841 \mathrm{u})$ & iutA and iss & O168 & A \\
\hline $2(281 \mathrm{lu})$ & traT,ibe $\mathrm{A}$, iut $\mathrm{A}, c v a \mathrm{C}, s t \times 2$, tsh and ompA & $\mathrm{O} 125$ & B1 \\
\hline $3(66 \mathrm{sp})$ & $c v a \mathrm{C}$, ompA and iss & O168 & A \\
\hline $4(52 h)$ & ompAand iss & $\mathrm{O} 27$ & A \\
\hline 5 (72li) & eae $\mathrm{A}$, traT, iutA, ompA, tsh and iss & $\mathrm{O} 27$ & B1 \\
\hline $6(14 l i)$ & traT, iutA,cvaC,ompAand iss & $\mathrm{O} 78$ & $\mathrm{D}$ \\
\hline 7 (70lu) & traT, iutA, cvaC, ompA, tsh and iss & $\mathrm{O} 78$ & B2 \\
\hline $8(87 h)$ & traT, iutA, cvaC, stx 1 , ompA, and iss & $\mathrm{O} 27$ & B1 \\
\hline $9(81 \mathrm{sp})$ & traT, iut $\mathrm{A}, c v a \mathrm{C}$, st $x 2$, ompA and iss & 0115 & B1 \\
\hline $10(4 \mathrm{~h})$ & traT, iutA, cvaC, stx2, ompA, and iss & 0157 & $\mathrm{D}$ \\
\hline $11(54 \mathrm{~h})$ & traT, iutA, stx2, ompA and tsh & O157 & B2 \\
\hline $12(12 \mathrm{sp})$ & traT, iutA, stx2, ompAand iss & O157 & B2 \\
\hline $13(2 \mathrm{t})$ & traT, iutA, stx 2 , ompAand iss & $\mathrm{O} 78$ & B2 \\
\hline 14 (100sp) & $\operatorname{tra\mathrm {T}}$, iutA, cvaC, stx2, ompA, tsh and iss & $\mathrm{O} 78$ & B2 \\
\hline $15(68 \mathrm{t})$ & traT, iutA, cvaC, ompAand iss & O157 & $\mathrm{D}$ \\
\hline
\end{tabular}

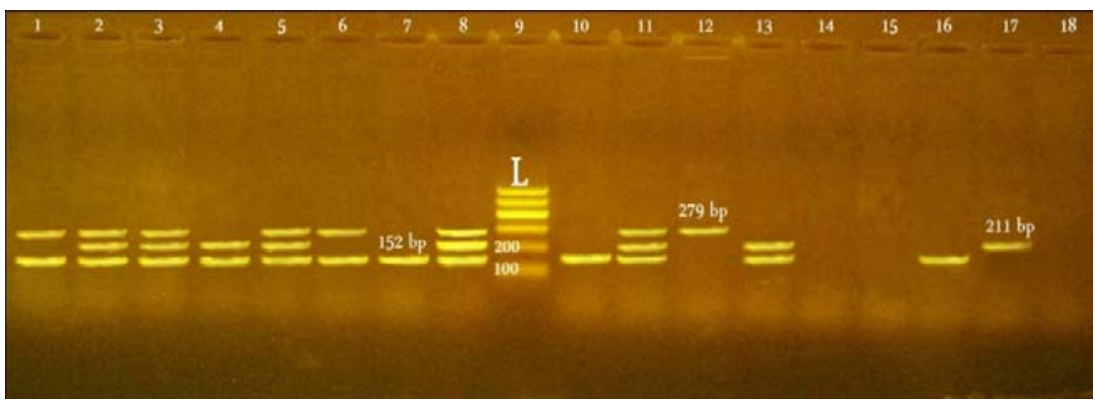

Fig. (1): Agarose gel electrophoresis of TspE4c2, chuA and yjaA genes among DNA products of of 15 E.coli isolates in a multiplex PCR Lane 9: 100-bp ladder, Lane 18: control negative, Lane 8: control positive. Lanes 1-7, 10,11,13 and 16: E.coli isolates had TspE4c2 virulence gene at $152 \mathrm{bp}$ Lane 2- 5, 11, 13 and17: E.coli isolate had yjaA virulence gene at 211 bp. Lane 1-6, 11 and 12: E.coli isolates had chuA virulence gene at $279 \mathrm{bp}$. 


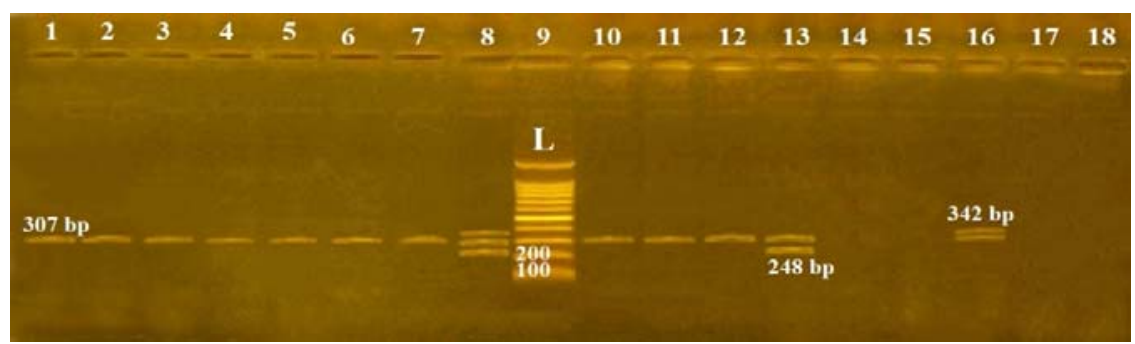

Fig. (2): Agarose gel electrophoresis of eaeA, traT and ibeA genes in E.coli isolates in multiplex PCR Lane 9: 100-bp ladder, Lane 18: control negative, Lane 8: control positive. Lane 13 E.coli isolate had eaeA virulence gene at $248 \mathrm{bp}$ Lanes 1-7 and 10-13 and 16: E.coli isolate had traT virulence gene at 307 bp. Lane 16: E.coli isolates had ibeA virulence gene at $342 \mathrm{bp}$.

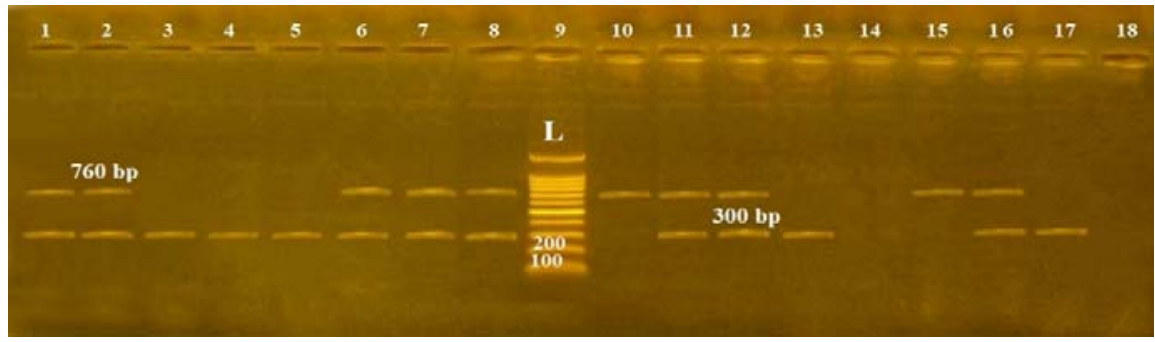

Fig. (3): Agarose gel electrophoresis of iutA and cvaC genes Lane 9: 100-bp ladder, Lane 18: control negative, Lane 8: control positive. Lane 1-7 and 11,12,13,16 and 17 E.coli isolates had iutA virulence gene at $300 \mathrm{bp}$ Lane 1,2, 6, 7, 10, 11, 12, 15 and 16: E.coli isolate had $c v a \mathrm{C}$ virulence gene at $760 \mathrm{bp}$.

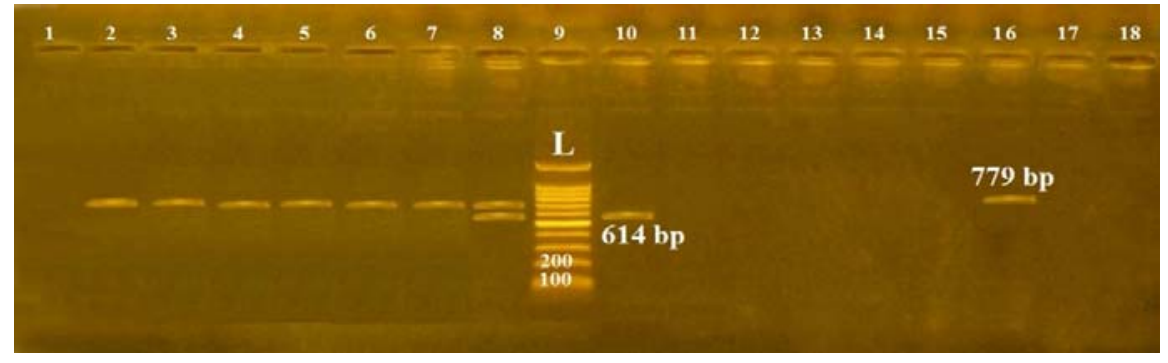

Fig. (4): Agarose gel electrophoresis of stx 1and stx2 virulence genes among DNA products of of 15 E.coli isolates in a multiplex PCR, Lane 9: 100-bp ladder, Lane 18: control negative, Lane 8: control positive. Lane10: E.coli isolate had stx1 virulence gene at 614bp Lane 2 -7and 16: E.coli isolates had stx2 virulence gene at $779 \mathrm{bp}$.

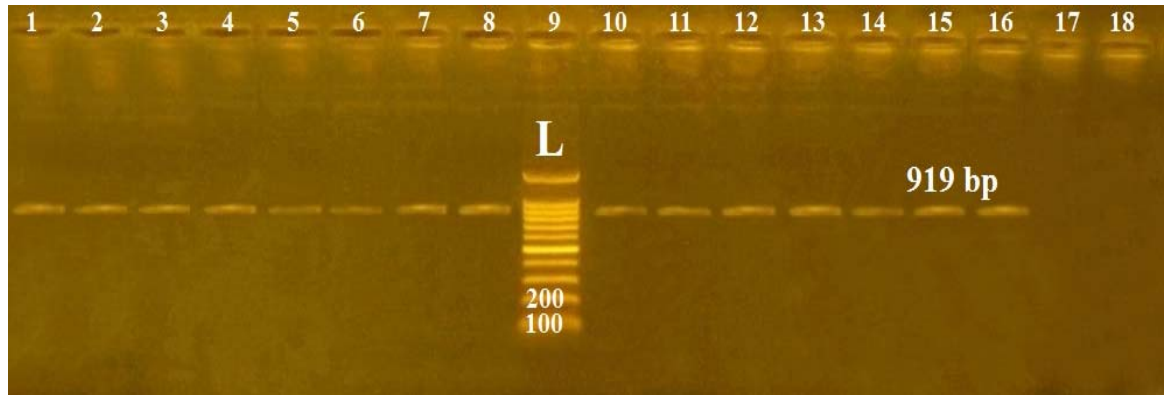

Fig. (5): Agarose gel electrophoresis of PCR- for amplification products of ompA gene of 15 E.coli isolates Lane 9: 100-bp ladder, Lane 18: control negative (reference strain), Lane 8: control positive (reference strain), Lanes 1-7and 10-16: E.coli isolates had ompA virulence gene at $919 \mathrm{bp}$. 


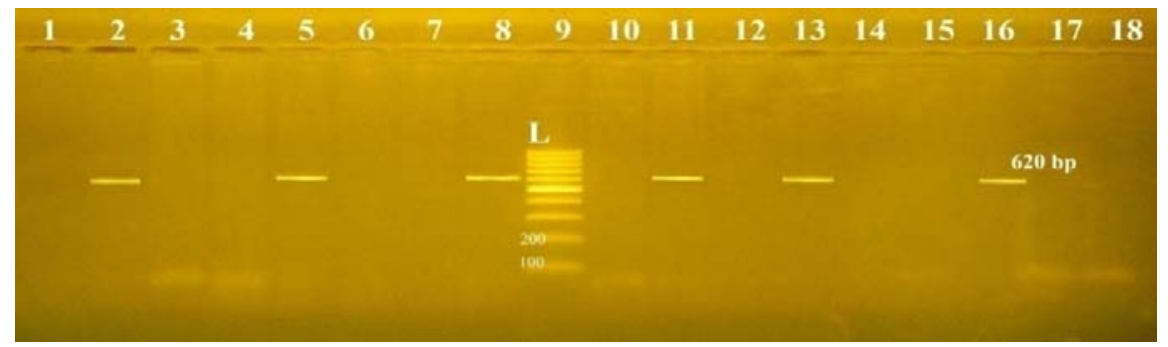

Fig. (6): Agarose gel electrophoresis of PCR- for amplification products of tsh gene of 17 E.coli isolates (Lane 9: 100-bp ladder, Lane 18: control negative (reference strain), Lane 8: control positive, Lanes 2, 5, 11, 13 and 16: E.coli isolates had tsh virulence gene at $620 \mathrm{bp}$.

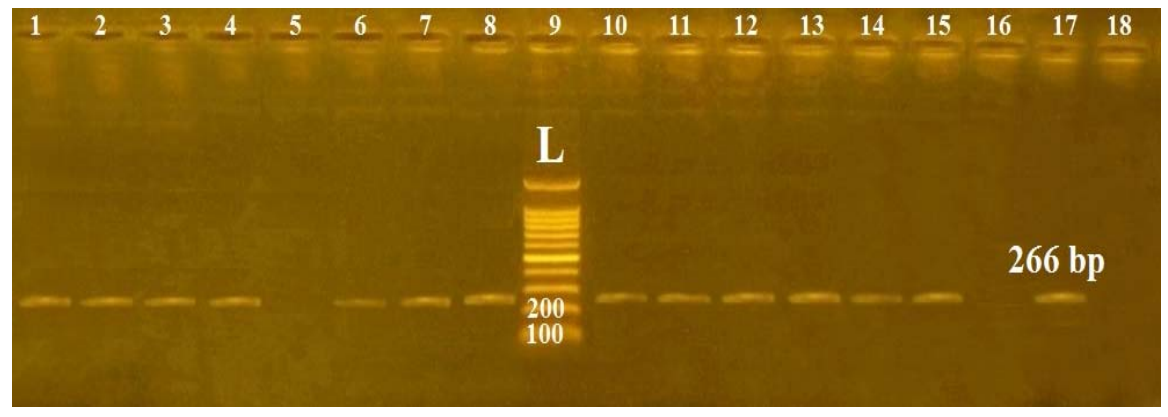

Fig. (7): Agarose gel electrophoresis of PCR- for amplification products of iss gene of 15 E.coli isolates (Lane 9: 100-bp ladder, Lane 18: control negative (reference strain), Lane 8: control positive, Lanes 14,6,7, 10- 15 and 17: E.coli isolates had iss virulence gene at $266 \mathrm{bp}$.

E. coli under study were deposited into gene bank under the following accession numbers 954329 and 954330.

\section{DISCUSSION}

APEC has been widely studied for its rule in extra intestinal infections which causes high economic losses in poultry industry (Barnes and Gross, 1997; Minarro et al., 2001; Assis et al., 2003;). The pathogenicity of an E.coli strain is based on the presence and expression of some potential virulence factors (Won et al., 2009). In spite of frequency variations, the following factors are significant including adhesion, invasion, colicin production, aerobactin presence, serum resistance and temperature sensitive haemagglutination (Dho and Lafont, 1982; Naveh et al., 1984; Rocha et al., 2002; Ngeleka et al., 2002; Brito et al., 2003; Delicato et al., 2003 and Mcpeake et al., 2005). In this study, 15 E.coli isolates were obtained from chickens with confirmed cases of colibacillosis and were screened for 11 virulence genes commonly associated with APEC and we discussed the association between these virulence genes and phylogenetic groups in which E.coli belonged to(A, B1, B2 and D). The PCR virulence gene detection revealed that the majority of pathogenic avian E.coli strains have 4 or more virulence related genes(Kwon et al., 2008). The genetic determiners and the proteins that accompanied colicin production are mainly located in plasmids, which are called Col factors (Luria and Suit 1987). Colicin V is found mainly in virulent bacteria involved in extra-intestinal infections affecting humans and animals (Gilson et al. 1987, Lior 1994) and it inhibits the bacterial growth, interfering with the potential of membrane formation (Yang and Konsky 1984).Colicin V provides a competitive advantage in colonization of the intestinal tract (Wooley et al., 1994), which indicates that the presence of either colV plasmid or 
its related sequences is associated with APEC virulence (Johnson et al., 2006 and 2008). This study showed high prevalence of genes harbored by this plasmid and aerobactin operon as (iss, cvaC, iutA and traT genes). The gene for colV synthesis, $c v a C$ was successfully amplified in $60 \%$ of tested $E$. coli isolates at $760 \mathrm{bp}$. Constituent with previous studies, $c v a C$ gene was found with the same percentage (Rodriguez- seik et al., 2005), other investigations found different results either higher $99.1 \%$ (McPeake et al., 2005) or lower 22\% (Rocha et al., 2002). iss gene has been detected with high frequency 13/15 $(86.7 \%)$. iss gene is an important gene responsible for serum resistance and was identified in pColV-I-K94 plasmids, the protein of which is related to cytotoxic complex inhibition (Binns et al. 1982).

This gene was detected in previous studies with levels ranging from 80 to $100 \%$ (Ewers et al., 2004; Zaho et al., 2005; Someya et al., 2007 and Kwon et al., 2008). The property of invading and multiplying presented by pathogens is influenced by iron availability, which is essential for growth in living cells (Neilands et al. 1985). The aerobactin system enables microorganisms to grow in iron free media at low concentration. E. coli especially uses this way of capture and transport (Rohrbach et al. 1995, Braun, 2003). The presence of operon aerobactin is in general related to ColV plasmids, although it can be chromosomal (Linggood et al. 1987and Johnson 1991). iutA gene was found in 12 of the examined isolates (80\%). Rodriguezseik et al., (2005), Johnson et al., (2008) and schouler et al., 2012) detected the outer membrane protein aerobactin receptor iutA gene with similar percentages $80.2 \%$, $80.8 \%$ and $82.7 \%$ respectively. While, other authors detected lower levels $46.8 \%$ (Gomis et al., 2001), 63\% (Delicato et al., 2003 ) and $23 \%$ (vandekerchove et al., 2005). Results showed that only 5 isolates $(33.3 \%)$ harbored the tsh gene (temperature sensitive haemagglutinine gene), Whereas it was found in $46.3 \%$ of the $E$. coli strains analyzed by zhao et al., (2005) and won et al., (2009). High levels of The plasmid related outer membrane protein gene traT $(80 \%)$ were reported in the tested E. coli isolates, the same percent were recorded by others researchers in different countries (Binns et al.,1982; Pfaff-McDonough et al., 2000 and Rodriguez- seik et al., 2005). The ompA gene encodes the episomal outer membrane protease that cleaves colicins (Cavard and Lazdunski 1990) was found in most of the tested isolates $(93.3 \%)$ some studies showed the same high detection rates (Rodriguez-Siek et al. 2005 and Kafshdouzan et al. 2013). Collectively, most of the plasmid related genes under study were found with high percent as previously mentioned in other studies and suggested that plasmids are widely distributed among APEC and that they might act as a reservoir of plasmidmediated virulence genes transmissible to other bacteria (Rodriguez- seik et al., 2005). All isolates in this study lacked $h l y \mathrm{~F}$ gene although this gene has been well documented in chickens suffering from colibacillosis(Van der Westhuizen and Bragg, 2012) and found with very high prevalence rates in different studies (Johnson et al. 2008; Kafshdouzan et al. 2013). Regarding to the occurrence of eaeA, st $x 1$, st $x 2$ genes in the isolates, only one isolate carried the eaeA gene $6.67 \%$, whereas it was detected with higher percentages in other studies (Dutta et al., 2011 and Kobayashi et al., 2011). Furthermore, stx 1 and st $x 2$ was found in 1 and 7 isolates respectively unlike other studies that found higher percentages of st $x 1$ and lower percentages of stx 2 (Stephan and Kuhn, 1999,Yngvild, 2001 and Sara et al, 2013). The gene associated with invasion ibeA was found with low incidence $(6.67 \%)$. whereas, other studies found ibeA gene in E. coli strains exhibted high number of virulence factors with higher percentages (31\%) (Cunha et al., 2014). Epidemiological survayes in many countries have classified most APEC strains into A and D (Ewers et al., 2007; Johnson 
et al., 2008 and Kobayashi et al., 2011). Results of this study showed that $33.3 \%$ of the examined strains belong to group B2, followed by group B1 (26.7\%), finally groups A and D were detected with $(20 \%)$ each. Phylogroup B2 is considered more virulent in ExPEC infection and frequently had the greatest number of virulence genes (Smith et al., 2007 and Mellata, 2013). This group is also found to be related to the pathogenic serogroups O157and O78. In this work, we sequenced iss and $c v a \mathrm{C} / c v i$ genes from E. coli serogroups $\mathrm{O} 78$ and O157. The results of the exiting study showed high homology between iss genes and other isolates deposited on the gene bank. Concerning $c v a C / c v i$ gene, results showed that it shared high level of identity ranged from (98-99\%) with other isolates previously deposited on the gene bank. Some studies have reported that the distribution of virulence factors in APEC is independent of the host and that APEC could pose a zoonotic risk via horizontal gene transfer between different $E$. coli strains strains (Ron 2006; Johnson et al. 2008; Mellata et al. 2009).

\section{CONCLUSION}

High prevalence of B2 phylo group strains which also possess the highest number of virulence genes, especially those carried on large plasmids as colV plasmid such as $c v a \mathrm{C}$, iss and tsh. This large plasmid may be transmitted to other E.coli or different microbes by horizontal gene transfer. The strong association of predicted iss, ompA and tsh proteins among different $E$. coli strains suggests that it could be a good antigen to detect and control avian pathogenic E. coli (APEC).

\section{REFERENCES}

Assis, M.T.Q.M., Gruber, G.L., Hofmeister, A.W.,Guimaraes, A.M.P. 2003. Avaliação do percentual de descartenacon denaçãoparcial de frangos.
RevistaNacional da Carne. 313:2231.

Barnes, J.H., Gross, W.B.1997. Colibacillosis. In: Calnek B.W., Barnes, H. J., Beard, C.W. Mcdogald, L.R., Saif, Y.M. (Ed.).Dis. of poultry. $10^{\text {th }}$ ed. Ames, IA, USA: Iowa State University Press.131139.

Barnes, H.J., Nolan, l.k., vaillancourt, J.A. 2008.Colibacillosis in Saif, Y.M., Fadly, A.M.(Eds.), Disease of poultry. Blackwell Publishing, Ames, I.A, PP.691-732.

Basu, S., Mukherjee, S.K., Hazra,A. and Mukherjee, M. 2013.Molecular characterization of uropathogenic Escherichia coli:nalidixic acid and ciprofloxacin resistance, virulent factors and phylogenetic background, Journal of Clinical and Diagnostic Research, 7(12): 2727-2731.

Bergeron, C.R., Prussing, C., Boerlin, P. 2012. Chicken as reservoir for extraintestinal pathogenic Escherichia coli in humans, Canada," Emerging Infect. Dis., 18(3): 415421.

Binns, M.M., Mayden, J., Levine, R.P. 1982. Further characterization of complement resistance conferred on Escherichia coli by the plasmid genes traT of R100 and iss of colV, I-K94. Infect. Immun. 35: 654-659.

Bisi-Johnson, M.A., Obi, C.L., Vasaikar, S.D., Baba, K.A., Hattori, T. 2011. Molecular basis of virulence in clinical isolates of Escherichia coli and Salmonella species from a tertiary hospital in the Eastern Cape, South Africa. Gut Pathogens. 3-9.

Braun, V. 2003. Iron uptake by Escherichia coli. Front Biosci.8:1409-1421. Brito, B.G., Gaziri L.C., Vidotto, M.C. 2003. Virulence factors and clonal relationships among Escherichia coli strains isolated from broiler chickens with cellulitis. Infect. Immun. 71:4175-4177. 
Calnek, B.W., Barnc, H.J., Charles, W.B., Larry, R.M. and Saif, Y.M. 1997. Diseases of poultry, $10^{\text {th }} \mathrm{Ed}$., Iowa State University Press, USA.

Cavard, D. and Lazdunski, C.1990. Colicin cleavage by omp $\mathrm{T}$ protease during both entry into and release from Escherichia coli cells. Bacteriol. J. 172 (2): 648-652.

Clermont, O., Bonacorsi, S., Bingen, E. 2000. Rapid and simple determination of the Escherichia coli phylogenetic group Appl. Environ. Microbiol.66:4555-4558.

Cunha, M.P.V., Oliveira, M.G.X., Oliveira, M.C.V., Silva, K.C., Gomes, C.R., Moreno, A.M. and Knöbl, T. 2014.Virulence Profiles,

Phylogenetic Background, and Antibiotic Resistance of Escherichia coli Isolated from Turkeys with Airsacculitis .The Scientific World J. Article ID 289024 (1-8).

Delicato, E.R., De Brito, B.G., Gaziri, L.C.J., Vidotto, M.C., 2003. Virulence-associated genes in Escherichia coli isolates from poultry with colibacillosis. Vet. Microbiol. 94:97-103.

Dho, M., Lafont, J.P. 1982. Escherichia coli colonization of the trachea in poultry: comparison of virulent and avirulent strains in Enterotoxigenic chickens. Avian Dis. 26:787-797.

Dipineto, L., Santaniello, A., Fontanella, M., Lagos, K., Fioretti, A. Menna, L.F. 2006. Presence of Shiga toxinproducing Escherichia coli O157:H7 in living layer hens. Letters in Applied Microbiology 43: 293-295.

Dutta, T.K., Roychoudhury, R., Bandyopadhyay, S., Wani, S.A., Hussain, I. 2011. Detection and characterization of shiga toxin producing Escherichia coli (STEC), enteropathogenic Escherichia coli (EPEC) in poultry birds with diarrhea. Indian Res. J. 133(5): 541-545.
Dziva F., Stevens, M.P. 2008. Colibacillosis in poultry: unravelling the molecular basis of virulence of avian pathogenic Escherichia coli in their natural hosts. Avi. Patho. 37(4): 355-366.

Edward, P.R., Ewing, W.H. 1972. Edward and Ewing's identification of Enterobacteriacae, $3^{\text {rd }}$ Ed. Burgess, Minneapolis.

Ewers, C., Janssen, T., Kiessling, S., Philipp, H.C., Wieler, L.H. 2004. Molecular epidemiology of avian pathogenic Escherichia coli (APEC) isolated from colisepticemiae in poultry. Vet. Microbiol.104 (1-2): 91101.

Ewers, C., Li, G., Wilking, H., Kiessling, S., Alt, K., Antao, E.M., Laturnus, C., Diehl, I., Glodde, S., Homeier, T., Bohnke, U., Steinruck, H., Philipp, H.C., Wieler, L.H. 2007.Avian pathogenic, uropathogenic, and newborn meningitis-causing Escherichia coli: how closely related are they? Int. J. Med. Microbiol.297:163-176.

Gilson, L., Mahanty, H.K., Kolter, R. 1987. Four plasmid genes are required for colicin V synthesis, export, and immunity. J. Bacteriol.169:24662470.

Gomis, S.M., Riddell, C., Potter, A.A., Allan, B.J. 2001. Phenotypic and genotypic characterization of virulence factors of Escherichia coli isolated from broiler chickens with simultaneous occurrence of cellulitis and other colibacillosis lesions. The Canadian J. of Vet. Res. $\quad 65$

(1): 1-6.

Jakobsen, L., Garneau, P., Bruant, G. 2012. Is Escherichia coli urinary tract infection a zoonosis? Proof of direct link with production animals and meat. European J.ofClin.Microbiol. Infect. Dis. 31(6): $\quad$ 1121- 1129.

Jeong, Y.W., Kim, T.E., Kim, J.H., Kwon, H.J. 2012. Pathotyping avian 
pathogenic Escherichia coli strains in

Korea. J. Vet. Sci., 13, 145-152.

Johnson, J.R. 1991. Virulence factors in Escherichia coli urinary tract infection. Clin. Microbiol. Rev. 4:80 128.

Johnson, J.R., Oswald, E., O’Bryan, T.T., Kuskowski, M.A., Spanjaard, L. 2002. Phylogenetic distribution of virulence-associated genes among Escherichia coli isolates associated with neonatal bacterial meningitis in the Netherlands. J. Infect. Dis. 185:774-784.

Johnson, T.J., Siek, K.E., Johnson, S.J. \& Nolan, L.K., 2006. DNA sequence of a ColV plasmid and prevalence of selected plasmid- encoded virulence genes among avian Escherichia coli strains. J. of Bacteriol.188: 745-758.

Johnson, T.J., Wannemuehler, Y., Doetkott, C., Johnson, S.J., Rosenberger, S.C., Nolan, L.K. 2008. Identification of Minimal Predictors of Avian Pathogenic Escherichia coli Virulence for Use as a Rapid Diagnostic Tool. Journal of Clinical Microbiology 46(12): 3987-3996.

Kafshdouzan, K., Salehi, T.Z., Nayeri, B., Madadgar, O., Yamasaki, S., Hinenoya, A. et al., 2013. Distribution of virulence associated genes in isolated Escherichia coli from avian colibacillosis Iranian J. of Vet. Med.7(1): 1-6.

Kaipainen, T., Pohianvitra, T.,Sphigel, N.,Pelkonen, S. 2002. Virulance factors of E.coli isolated from bovine clinical mastitis. Vet. Microbiol. J. 26(1): 37-46.

Kaper, J.B. 2005. Pathogenic Escherichia coli. Int. J. Med. Microbiol.295: 35535.

Kobayashi, R.K.T., Aquino, I., Ferreira, A.L.D.S., Vidotto, M.C. 2011. EcoR phylogenetic analysis and virulence genotyping of avian pathogenic Escherichia coli strains and Escherichia coli isolates from commercial chicken carcasses in southern Brazil. Foodborne Path.and Dis. 8(5): 631-634.

Kwon, S.G., Cha, S. Y., Choi, E.J., Kim, B., Song, H.J. Jang, H.K. 2008. Epidemiological prevalence of avian pathogenic E. coli differentiated by multiplex PCR from commercial chickens and hatchery in Korea. Bacteriology and Virology J. 38(4): 179-188.

Linggood, M.A., Roberts, M., Ford, S., Parry, S.H., Williams, P.H. 1987. Incidence of the aerobactin iron uptake system among Escherichia coli isolates from infections of farm animals.J. Gen. Microbiol. 133: 835-842.

Lior, H. 1994. Classification of Escherichia coli, p.31-72. In:Gyles, C.L.(ed.), Escherichia coli in Domestic Animals and Humans. CAB Inter-national, Wallington, Oxon, UK.

Luria, S.E., Suit, J.L. 1987. Colicins and COL plasmids, p.1615-1624. In: Neidhardt, F.C. (ed.), Escherichia coli and Salmonella Typhimurium: Cellular and molecular biology. Vol.2. American Society of Microbiology, Washington, DC.

McPeake, S.J.W., Smyth, J.A., Ball, H.J. 2005. Characterization of avianpathogenic Escherichia coli (APEC) associated with colisepticemia compared to fecal isolates form healthy birds. Vet. Microbiol. 110:245-253.

Mellata, M. 2013. Human and avian extraintestinal pathogenic Escherichia coli:

infections, zoonotic risks, and antibiotic resistance trend Foodborne Pathogens and Diseases.10(11): 916932.

Mellata, M., Touchman, W.J., Curtiss, R. III. 2009. Full sequence and comparative analysis of the plasmid pAPEC-1 of avian pathogenic E.coli 
v7122 (O78:K89:H9). PLoSONE 4: $1-12$.

Minarro, S., Linhares, G.F.C., Andrade, M.A., Rocha, P.T., Santana, A.P. 2001. Envolvimento de Escherichia coli, de Mycoplasma gallisepticume de Mycoplasma synoviaeemlesões de sacosaéreosem frangosabatidos no Estado de Goiás. Ciência Animal Brasileira. 2(2): 111-117.

Moreno, E., Andreu, A., Pigrau, Kuskowski, C.M.A., Johnson, J.R. Prats, G. 2008. Relationship between Escherichia coli strains causing acute cystitis in women and the fecal E. coli population of the host. J. of Clin. Microbiol. 46(8): 2529-2534.

Naveh, M.W., Zusman, T., Skutelsky, E., Ron, E.Z. 1984. Adherence piliin avian strains of Escherichia coli: effect on pathogenicity. Avian Dis. 28:651-661.

Neilands, J.B., Bindereif, A., Montgomerie, J.Z. 1985. Genetic basis of iron assimilation in pathogenic Escherichia coli. Curr. Top. Microbiol. Immunol.118:179-195.

Ngeleka, M., Brereton, L., Brown, G., Fairbrother, J.M. 2002. Pathotypes of avian Escherichia coli as related to tsh-, pap-, pil-, and iuc- DNA sequences, and antibiotic sensitivity of isolated from internal tissues and the cloacae of broilers. Avian Dis.46:143-152.

Pfaff-McDonough, S.J., Horne, S.M., Giddings, C.W., Ebert, J.O. Doetkott, C., Smith, M.H., Nolan. L.K. 2000. Complement resistance related traits among Escherichia coli isolates from apparently healthy birds and birds with colibacillosis. Avian Dis. 44:23-33.

Piva, I.C., Pereira, A.L., Ferraz, L.R., Silva, R.S.N., Vieira, A.C., Blanco, J.E., Blanco, M., Blanco, J., Giugliano, L.G. 2003.Virulence Markers of Enteroaggregative Escherichia coli Isolated from Children and Adults with Diarrhea in Brasília, Brazil. J. of clin Microbiol. 1827-1832.

Rocha, A.C., Silva, A.B., de Brito, A.B., Moraes, H.L., Pontes, A.P., Ce, M.C., Nascimento, V. Salle, C.T., 2002. Virulence factors of avian pathogenic Escherichia coli isolated from broilers from the south of Brazil. Avian Dis. 46:749-753.

Rodriguez-Siek, K.E., Giddings, C.W., Doetkott, C. Johnson, T.J.

Fakhr, M.K., Nolan, L.K. 2005. Comparison of Escherichia coli isolates implicated in human urinary tract infection and avian colibacillosis. Microbiology. 151:2097-2110.

Rohrbach, M.R., Braun, V., Koster, W. 1995. Ferrichrome transport in Escherichia coli K-12: altered substrate specificity of mutated periplasmic FhuD and interaction of FhuD with the integral membrane protein FhuB. J. Bacteriol. 177: 71867193.

Ron, Z.E. 2006. Host specificity of septicemic Escherichia coli:human and avian pathogens. Curr. Opin. Microbiol. 9: 28-32.

Russo, T.A., Johnson, J.R. 2000. Proposal for a new inclusive designation for extraintestinal pathogenic isolates of Escherichia coli: ExPEC. J. Infect. Dis. 181:1753-1754.

Sarah, A.Y., Ammar, A.M., Ahmed, D.A. 2013. Serological and Molecular Typing of Avian Pathogonic E.coli Origenating from Outbreaks Of Colibacllosis In Chicken Flocks. Int. J. Of Sience 6(14): 2082-2088.

Schouler, C., Schaeffer, B., Brée, A., Mora, A., Dahbi, G., Biet, F., 2012. Diagnostic strategy for identifying avian pathogenic Escherichia coli based on four patterns of virulence genes. J. of Clin. Microbiol. 50(5): 1673-1678.

Smith, J.L., Fratamico, P.M., Gunther, N.W. 2007. Extraintestinal pathogenic Escherichia coli, 
Foodborne Path. and Dis. 4(2):134163.

Someya, A., Otsuki, K., Murase,T. 2007. Characterization of Escherichia coli strains obtained from layer chickens affected with colibacillosis in a commercial egg-producing farm. J. Vet. Med. Sci. 69(10): 10091014.

Stephan, R., Kuhn, k., 1999. Prevalence of verotoxin producing E.coli

(VTEC) in bovine coli mastitis and other antibiotic resistance patterns. Journal of Vet. Med. Seriec. B. 46(6):423-427.

Takahashi, A., Kanamaru, S. Kurazono, H. 2006. Escherichia coli isolates associated with uncomplicated and complicated cystitis and asymptomatic bacteriuria possess similar phylogenies, virulence genes, and O-serogroup profiles. J. of Clin. Microbiol. 44(12): 45894592.

Tivendale, K.A., Logue, C.M. Kariyawasam, S. 2010. Avian pathogenic Escherichia coli strains are similar to neonatal meningitis E. coli strains and are able to cause meningitis in the rat model of human disease.

Infection and Immunity. 78(8): 3412 3419.

VanderWesthuizen, A.W., Bragg, R.R., 2012. Multiplex polymerase chain reaction for screening avian pathogenic Escherichia coli for virulence genes. Avi. Path.41(1): 33-40.

Vandekerchove, D., Vandemaele, F., Adriaensen, C., Zaleska, M. 2005. Virulence-associated traits in avian Escherichia coli: comparison between isolates from colibacillosis-affected and clinically healthy layer flocks. Vet. Microbiol.108:75-87.

Vincent, C., Boerlin, P. Daignault, D. 2010. Food reservoir for Escherichia coli causing urinary tract infections. Emerging Infec.Dis.16(1):88- 95.

Won, G., Moon, B., Oh, I., Matsuda, K., Chaudhari, A.A., Hur, J., Eo, S., Yu, I., Lee, Y., Lee, Y., Kim, B., Lee, J.H. 2009. Profiles of virulenceassociated of avian pathogenic Escherichia coli isolates from chickens with colibacillosis. Poult. Sci. 46:260-266.

Wooley, R.E., Brown, J., Gibbs, P.S., Nolan, L.K., Turner, K.R. 1994. Effect of normal intestinal flora of chickens on colonization by virulent colicin V-producing, avirulent, and mutant colicin Vproducing vian Escherichia coli. Avian Dis. 38:(1): 141-145.

Yaguchi, K., Ogitani, T., Osawa, R., Kawano, M., Kokumai, N., Kaneshige, T., Noro, T., Masubuchi, K., Shimizu, Y. 2007. Virulence Factors of Avian Pathogenic Escherichia coli Strains Isolated from Chickens with Colisepticemia in Japan. Avian Dis. J. 51(3):656-62.

Yang, C.C., Konisky, J. 1984. Colicin V treated Escherichia coli does not generate membrane potential. J. Bacteriol.158: 757-759.

Yngvild, W. 2001. Zoonotic Escherichia coli. Acta. Vet. Scand. Suppl. 95: 79-84.

Zhao, S., Maurer, J.J., Hubert S., De Villena, J.F., McDermott, P.F., Meng, J., Ayers, S., English, L., White, D.G. 2005. Antimicrobial susceptibility and molecular characterization of avian pathogenic Escherichia coli isolates. Vet. Microbiol. J. 107 (3-4): 215-224.

Zhao, L. Gao, S. Huan, H. Xu, X. Zhu, X. Yang, W., Gao, Q., Liu, X.2009. Comparison of virulence factors and expression of specific genes between uropathogenic Escherichia coli and avian pathogenic $E$. coli in a murine urinary tract infection model and a chicken challenge model Microbiology. 155:1634-1644. 